\title{
Study of spectrum of head and neck lesions diagnosed on fine needle aspiration cytology (FNAC)
}

\author{
Meenai F.J. ${ }^{1}$, Jain R. ${ }^{2}$, Ojha S. ${ }^{3}$, Sawke G.K. ${ }^{4}$, Gupta $S .^{5}$ \\ ${ }^{1}$ Dr. Farah Jalaly Meenai, Associate Professor, ${ }^{2}$ Dr. Rubal Jain, Assistant Professor, ${ }^{3}$ Dr. Sandeep Ojha, Associate \\ Professor, ${ }^{4}$ Dr. Gopal Krishna Sawke, Professor and Head, ${ }^{5}$ Dr. Sonam Gupta, Demonstrator, all authors are affiliated \\ with Department of Pathology, Chirayu Medical College \& Hospital, Bhopal, Madhya Pradesh, India.
}

Corresponding Author: Dr. Rubal Jain, A-152, Shahpura, 1st Floor, Behind Shekhar Hospital, Bhopal (M.P). E-mail: drrubaljain@gmail.com

\begin{abstract}
Background: Fine needle aspiration cytology (FNAC) is a cost effective and minimally invasive diagnostic outdoor procedure for head and neck lesions with high efficacy. Aims and objectives: To evaluate the spectrum of head and neck lesions with FNAC, its efficacy and correlating thefindings with histopathological diagnosis wherever possible. Materials and Methods: Retrospective observational study of 597 patients evaluated with FNAC for head and neck lesions from 2014 January to December 2016. Data were retrievedfrom the stored reports in Department of Pathology and the results were analyzed. Clinical and radiological details were obtained from patients' file wherever deemed necessary from Medical Record Department of the institute. Results: Most common site aspirated were Lymph nodes (64\%) followed by Thyroid (18.3\%), skin (5.7\%) andsoft tissue (4.02\%). Most common diagnosis in lymph node FNAC was metastatic lymphadenopathy (37.4\%) followed by reactive lymphadenitis $(31.9 \%)$ and granulomatous lymphadenitis (20.4\%). Benign lesions were most common among thyroid swellings $(70.1 \%)$ followed by papillary carcinoma $(12.9 \%)$. Majority of salivary gland lesions were benign neoplasm (52.4\%). Most common skin and soft tissue lesions were epidermal inclusion cyst (52.9\%) and lipoma (66.7\%) respectively. Histopathological diagnosis was available in $47.2 \%$ of cases with $94.7 \%$ concordance. Conclusion: Head and neck lesions are common superficial lesions that can be easily diagnosed oncytology. It differentiates inflammatory/infectionfrom neoplastic lesions and avoids unnecessary surgeries and expedites the management. FNAC is cost effective and accurate diagnostic procedureand can be recommended as a first line investigation.
\end{abstract}

Keywords: Cytology. Fine Needle Aspiration Cytology (FNAC), Head and Neck, Swelling

\section{Introduction}

Fine needle aspiration cytology (FNAC) is first line investigation in approach towards diagnosis of superficial and deep seated lesions of head and neck. FNAC is particularly relevant in head and neck location because of easy accessibility, rapidity, minimally invasive, accurate and cost effective procedure which is accepted by majority of the patients.

It may help in triage of neoplastic and non-neoplastic lesions and thus helps to avoid unnecessary surgeries in non-neoplastic lesions thusexpediting the process of management ofmalignant lesions [1,2]. It causes minimal trauma to the patient and carries virtually no risk andcomplications. Swellings within the region of

Manuscript received: $15^{\text {th }}$ November 2017

Reviewed: $24^{\text {th }}$ November 2017

Author Corrected: $30^{\text {th }}$ November 2017

Accepted for Publication: $4^{\text {th }}$ December 2017 head and neck, especially salivary gland and thyroid gland lesions can be readily diagnosed using this technique [3, 4]. Spectrum of lesions of head and neck comprises of developmental, inflammatory and neoplastic conditions. The most common sites which are encountered for FNAC in head and neck region are lymph nodes, thyroid, salivary gland, skin and soft tissue swellings. Lesions like carotid body tumours, branchial cyst, thyroglossal cyst, cystic hygroma, pharyngeal pouch and lump of skin appendages are less commonly encountered [2].

FNAC is both diagnostic and therapeutic in cystic swellings [5]. Fine needle aspiration cytology is helpful for the diagnosis of salivary gland tumors where it can differentiate between a malignant and a benign tumor with over $90 \%$ accuracy [6]. 
Original Research Article

FNAC is particularly helpful in the work-up for cervical masses and nodules because biopsy of cervical adenopathy should be avoided unless all other diagnostic modalities have failed to establish a diagnosis [7]. It could be considered as diagnostic procedure of choice in cases of oral carcinoma presenting with neck node metastasis because positive metastatic lymph node on FNAC may avoid biopsy of oral lesions can be avoided if node is positive for metastasis.

In 1930, Martin introduced this technique for evaluation of head and neck lesion and the procedure has since then being used for all palpable swellings [8, 9]. FNAC assessment needs relevant clinical history of patient as well as radiological findings to make plausible diagnosis.

The purpose of this study was to evaluate the wide spectrum of lesions diagnosed on FNAC in patients with head and neck swellings and to know the efficacy of FNAC in diagnosing head and neck lesions.

\section{Material and Methods}

Place of study- Department of Pathology, Chirayu Medical College and Hospital. Type of study- This was a retrospective observationalstudy.
Sampling methods and collection- Data were retrieved from the stored reports ofpatients in Department Of Pathology and results were tabulated, analyzed and studied. Clinical and radiological details were obtained from patients files. Inclusion and exclusion criteriaAll the cases of head and neck cases were segregated from other lesions which were aspirated over a period of two years (January 2015 to December 2016). Relevant clinical and demographic details were noted and tabulated. This study also included FNA performed under ultrasound guidance. Both air dried and alcohol fixed smears stained with May Grundwald Giemsa (MGG) and Papanicalaou (PAP) stain respectively and were studied. Results were also correlated with special stains like Ziehl Nelson (ZN) stain wherever applicable.

The sites of FNAC were classified as lymph nodes, thyroid, skin, soft tissue, salivary gland, oral cavity, nasal cavity, parathyroid, orbit and miscellaneous where exact site or location cannot be ascertained. Statistical methods- Data was tabulated, slides were reviewed wherever necessary and the percentages were calculated for estimating frequency of various pathological conditions. The cytological diagnosis was correlated with histopathology wherever available and the concordance rate, sensitivity, specificity value were calculated keeping histopathology diagnosis as gold standard using the statistical program Epi-info.

\section{Result}

In present study, out of 1800 patients enrolled for FNAC during study period, 597 patients presented with head and neck swellings. Patients'age ranged from 10 months to 84 years of age with male to female ratio of 1.3:1.

Incidence of lymph node lesions was highest in 382 cases (64 \%) followed by thyroid lesion in 109 cases (18.25\%), skin lesions in 34 cases $(5.7 \%)$, soft tissue in 24 (4\%) and salivary gland in 21 cases $(3.5 \%)$. Distribution of lesions with gender distribution was as in Table 1.

Table-1: Distribution of Lesions in Head and Neck FNAC and Gender distribution (Total n=597)

\begin{tabular}{|c|c|c|c|}
\hline Organ involved & Total cases & Male & Female \\
\hline Lymph node & $382(64 \%)$ & 239 & 82 \\
\hline Thyroid & $109(18.3 \%)$ & 27 & 12 \\
\hline Skin & $34(5.7 \%)$ & 16 & 08 \\
\hline Soft Tissue & $24(4.02 \%)$ & 16 & 05 \\
\hline Salivary gland & $21(3.5 \%)$ & 12 & 04 \\
\hline Oral and nasal cavity & $16(2.7 \%)$ & 01 & 01 \\
\hline Parathyroid & $02(0.3 \%)$ & 00 & 02 \\
\hline Orbit & $01(0.2 \%)$ & 06 & $\mathbf{2 5 8}(\mathbf{4 3 . 2 \%})$ \\
\hline
\end{tabular}

The distribution of various sites aspirated and their cytological diagnosis is illustrated in Table 2. 


\section{Original Research Article}

Table-2: Distribution of lesion of head and neck with cytological diagnosis.

\begin{tabular}{|c|c|c|c|c|}
\hline Site & Total cases & Lesions & Cases & $\%$ \\
\hline \multirow[t]{6}{*}{ Lymph Nodes } & \multirow[t]{6}{*}{382} & Metastasis & 141 & $36.9 \%$ \\
\hline & & Reactive Lymphadenitis & 118 & $30.9 \%$ \\
\hline & & Granulomatous & 74 & $19.4 \%$ \\
\hline & & Lymphoma & 29 & $7.6 \%$ \\
\hline & & Acute inflammation & 05 & $1.3 \%$ \\
\hline & & Inconclusive & 15 & $3.9 \%$ \\
\hline \multirow[t]{3}{*}{ Thyroid } & \multirow[t]{3}{*}{109} & Benign lesion \& Thyroiditis & 75 & $68.8 \%$ \\
\hline & & neoplasm & 32 & $29.2 \%$ \\
\hline & & Inconclusive & 2 & $1.8 \%$ \\
\hline \multirow[t]{4}{*}{ Salivary Gland } & \multirow[t]{4}{*}{21} & Inflammatory & 5 & $23.8 \%$ \\
\hline & & Benign neoplasm & 11 & $52.4 \%$ \\
\hline & & Malignant & 4 & $19 \%$ \\
\hline & & Inconclusive & 1 & $4.8 \%$ \\
\hline \multirow{4}{*}{ Skin } & \multirow{4}{*}{34} & Epidermal inclusion cyst & 18 & $52.9 \%$ \\
\hline & & Inflammatory lesion & 10 & $29.4 \%$ \\
\hline & & Granulation & 5 & $14.7 \%$ \\
\hline & & Inconclusive & 1 & $2.9 \%$ \\
\hline \multirow[t]{6}{*}{ Soft Tissue } & \multirow[t]{6}{*}{24} & Lipoma & 16 & $66.7 \%$ \\
\hline & & Benign spindle cell neoplasm & 4 & $16.7 \%$ \\
\hline & & Lymphangioma & 1 & $4.2 \%$ \\
\hline & & Chordoma & 1 & $4.2 \%$ \\
\hline & & Sarcoma & 1 & $4.2 \%$ \\
\hline & & Inconclusive & 1 & $4.2 \%$ \\
\hline \multirow{3}{*}{ Oral Cavity } & \multirow{3}{*}{13} & Round cell tumor & 1 & $7.7 \%$ \\
\hline & & Mucococele & 1 & $7.7 \%$ \\
\hline & & Squamous cell carcinoma & 11 & $84.6 \%$ \\
\hline Orbit & 1 & Round cell tumor & 1 & $100 \%$ \\
\hline Parathyroid & 2 & Parathyroid Adenoma & 2 & $100 \%$ \\
\hline \multirow[t]{2}{*}{ Nasal Cavity } & \multirow[t]{2}{*}{3} & Squamous cell carcinoma & 2 & $66.6 \%$ \\
\hline & & $\begin{array}{c}\text { Metastasis of Renal Cell } \\
\text { Carcinoma }\end{array}$ & 1 & $33.3 \%$ \\
\hline \multirow{3}{*}{$\begin{array}{l}\text { Miscellaneous } \\
\text { lesion }\end{array}$} & \multirow{3}{*}{8} & Benign Cystic lesion & 3 & $37.5 \%$ \\
\hline & & Brachial cleft cyst & 1 & $12.5 \%$ \\
\hline & & Inflammatory & 4 & $50 \%$ \\
\hline Total & 597 & & 597 & \\
\hline
\end{tabular}

Among Lymph node swellings, the highest number of cases were of non-neoplastic lesion (53.6\%) of which majority were reactive $(31.9 \%)$, followed by granulomatous lymphadenitis $(78 \%)$ and acute lymphadenitis $(1.3 \%)$. Malignant lesions were $45 \%$ of which most common were metastatic carcinomas from different sites mostly sqaumous in originfollowed by hematolymphoid malignancies (7.6\%). Out of 29 cases of hematolymphoid malignancy, majority of the cases were Non Hodgkins Lymphoma (20 cases, 69\%), followed by Hodgkin's lymphoma (7 cases, 24.1\%), one case each ofmyeloid sarcoma and follicular dendritic cell sarcoma. Fine needle aspiration was inconclusive in $1.3 \%$ of cases. 


\section{Original Research Article}

Amongst the thyroid swellings, FNAC revealed $68.8 \%$ of Non-neoplastic lesions including colloid goiter and thyroiditis. Where as neoplastic lesions comprised of $29.4 \%$ of which most common tumor diagnosed was papillary thyroid carcinoma (PTC) comprising of total 22 cases, followed by 4 cases diagnosed as follicular neoplasm (3.7\%), 3 cases each of medullary thyroid carcinoma and anaplastic carcinoma of thyroid (2.8\%). Thyroid lesions had female preponderance with male: female ratio of approximately 1:3.

A total of 21 cases of salivary gland lesions were aspirated, which accounted for $3.5 \%$ of total Head and Neck- swellings with male predominance. Most common lesions were benign (47.6\%) and comprised 6 cases of pleomorphic adenoma, 2 cases of sialadenosis, and 2 benign lymphoepithelial lesions.

Malignant neoplasms were second most common and comprised of Adenoid cystic carcinoma (3 cases) and one case each of mucoepidermoid carcinoma, acinic cell carcinoma, and carcinoma- ex- pleomorphic adenoma. There were 4 cases diagnosed as inflammatory lesions of which 3 cases showed features of chronic sialadenitis and one case was of acute sialadenitis.

Thirty four cases of skin lesions located in head and neck region were aspirated, of which the most common lesion was epidermal inclusion cyst (52.9\%) followed by other inflammatory lesions (29.4\%). Five cases of malignancy were diagnosed of which three cases were of scar recurrence inknown case of oral squamous carcinoma and one case each of subcutaneous deposits of thyroid carcinoma and primary squamous cell carcinoma of skin.

Soft tissue lesions were also aspirated of which lipoma was most common (66.7\%) and was followed by benign spindle cell neoplasm (16.7\%) and one case each of lymphangioma, chordoma, malignant spindle cell sarcoma. Thirteen cases of intraoral lesions were also aspirated composed of 8 cases of squamous carcinoma, 3 cases of pleomorphic adenoma and one case each of mucocele and round cell tumor which was later diagnosed as primitive neuroectodermal tumor.

Other sites which were also aspirated were orbit (1 case of rhabdomyosarcoma), two cases of parathyroid adenoma, 3 cases of nasal cavity (two cases of squamous carcinoma and one case was of metastasis of renal cell carcinoma). There were 2 cases of thyroglossal cysts, 2 cases of Paraganglioma, one case of branchial cleft cyst and 3 inflammatory lesions whose site of origin cannot be ascertained.

Histopathological diagnosis was available in $47.2 \%$ of cases of which cytology was concordant with histopathology in $94.7 \%$ of cases and was discordant in $5.6 \%$. Histopathological correlation with cytological diagnosis was as in Table 3 while reason for discordant cases was as in Table 4.

Table-3: Cyto- histopathological correlation of Head and neck lesions.

\begin{tabular}{|c|c|c|c|c|}
\hline Organ involved & Total cases & $\begin{array}{c}\text { Histopath diagnosis } \\
\text { available }\end{array}$ & Concordant & Discordant \\
\hline Lymph node & 382 & 182 & 176 & 6 \\
\hline Thyroid & 109 & 50 & 47 & 1 \\
\hline Skin & 34 & 7 & 10 & 2 \\
\hline Soft Tissue & 24 & 12 & 9 & 1 \\
\hline Salivary gland & 21 & 10 & 3 & 0 \\
\hline Oral Cavity & 13 & 11 & 1 & 1 \\
\hline Nasal Cavity & 03 & 3 & 1 & 0 \\
\hline Parathyroid & 02 & 2 & 3 & 1 \\
\hline Orbit & 01 & 4 & $\mathbf{2 6 7}(\mathbf{9 4 . 7} \%)$ & $\mathbf{1 5}(\mathbf{5 . 3} \%)$ \\
\hline
\end{tabular}


Original Research Article

Table-4: Distribution of cyto- histopatholgical discordant cases and reasons.

\begin{tabular}{|c|c|c|c|c|}
\hline & Site of FNAC & Cytological Diagnosis & Histological Diagnosis & Type of error \\
\hline Case 1 & Lymph Node & Acute Lymphadenitis & $\begin{array}{c}\text { Cystic metastasis of } \\
\text { squamous cell carcinoma }\end{array}$ & Sampling \\
\hline Case 2 & Lymph Node & Granulomatous & $\begin{array}{c}\text { Metastatic signet ring } \\
\text { adenocarcinoma }\end{array}$ & Interpretation \\
\hline Case 3 & Lymph Node & Granulomatous & Hodgkin's lymphoma & Interpretation \\
\hline Case 4 & Lymph Node & Reactive & $\begin{array}{c}\text { Low grade Non Hodgkins } \\
\text { Lymphoma }\end{array}$ & $\begin{array}{c}\text { NA as biopsy was } \\
\text { advised to rule out } \\
\text { NHL }\end{array}$ \\
\hline Case 5 & Lymph Node & Reactive & $\begin{array}{c}\text { Kikuchi like necrotizing } \\
\text { lymphadenitis }\end{array}$ & Sampling \\
\hline Case 6 & Lymph Node & Reactive & Granulomatous & Sampling \\
\hline Case 7 & Thyroid & PTC & Hyperplastic Goitre & Interpretation \\
\hline Case 8 & Thyroid & PTC & Goitre with degeneration & Interpretation \\
\hline Case 9 & Thyroid & Hyperplastic Goitre & PTC & Sampling \\
\hline Case 10 & Parathyroid & $\begin{array}{c}\text { Follicular Neoplasm of } \\
\text { Thyroid }\end{array}$ & Parathyroid Adenoma & $\begin{array}{c}\text { Improper clinical } \\
\text { details }\end{array}$ \\
\hline Case 11 & Skin & Inflammatory lesion & Scar recurrence of SCC & Sampling \\
\hline Case 12 & Soft Tissue & $\begin{array}{l}\text { Benign spindle cell } \\
\text { lesion }\end{array}$ & Angiosarcoma & Interpretation \\
\hline Case 13 & Soft Tissue & $\begin{array}{l}\text { Malignant spindle cell } \\
\text { sarcoma }\end{array}$ & Ancient Schwannoma & Interpretation \\
\hline Case 14 & Salivary Gland & $\begin{array}{c}\text { Adenoid cystic } \\
\text { carcinoma }\end{array}$ & Pleomorphic adenoma & Interpretation \\
\hline Case 15 & Miscellaneous & PTC & Paraganglioma & Interpretation \\
\hline
\end{tabular}

\section{Discussion}

FNAC is arapid diagnostic test in the initial assessment of the head and neck lesions which are superficial and easy to access. It has inherent advantage of being an outpatientprocedure, does not require sedation or anaesthesia, minimally painful and takes only few minutes to perform compared to time consuming, complicated and invasivebiopsy procedure [10].

Comparative evaluation of various head and neck lesions was done with other similar studies as in Table 5.

In this study, most common organ aspirated was lymph-node (64\%) and most common diagnosis was metastatic lymphadenopathy which is in discordance with other authors [10-12] who reported reactive lymphadenitis and Valiya LG [13] who reported granulomatous lymphadenopathy as most common lesion. The distribution of lymph node cytological assessment in various studies was as in Table 6.

Table-5: Comparison of results of FNAC of head and neck studies

\begin{tabular}{|c|c|c|c|c|}
\hline Study & Lymphnode & Thyroid & Salivary Gland & Soft Tissue \\
\hline Nanik J (10) & $64.3 \%$ & $17.5 \%$ & $4.8 \%$ & $13.5 \%$ \\
\hline Kishor H.et.al.(11) & $39.58 \%$ & $31.25 \%$ & $18.75 \%$ & $7.29 \%$ \\
\hline Sreedevi P (13) & $50.32 \%$ & $44.07 \%$ & $3.28 \%$ & $2.3 \%$ \\
\hline Present study & $63.98 \%$ & $18.25 \%$ & $3.5 \%$ & $14.3 \%$ \\
\hline
\end{tabular}


Original Research Article

Table-6: Comparison of results in Lymph-node Lesion.

\begin{tabular}{|c|c|c|c|c|}
\hline Lesion & Valiya LG [13] & Kishore H. [11] & Sreedevi P [12] & Present Study \\
\hline Reactive lymphadentitis & $28.79 \%$ & $35.08 \%$ & $51.63 \%$ & $28.53 \%$ \\
\hline Non-specific inflammation & $19.13 \%$ & 12.80 & 9.15 & $3.4 \%$ \\
\hline Granulomatous lesions & 30.12 & 47.36 & 27.4 & $18.84 \%$ \\
\hline Metastasis & 19.80 & 3.50 & 5.88 & $36.38 \%$ \\
\hline Lymphoma & 2.16 & 0.87 & 5.88 & $7.59 \%$ \\
\hline Inconclusive & - & - & - & $5.23 \%$ \\
\hline
\end{tabular}

This difference is probably due to the fact that our hospital is a tertiary care centre with well-established oncology unit hence the high rates of referral of cancer patients. Most common primary formetastatic lesion was found to be oral cavity and upper respiratory tractsquamous cell carcinoma followed by duct carcinoma breast. The sensitivity of FNAC for metastatic lymph nodes varies from $97.9 \%$ to $100 \%$ with nearly $100 \%$ specificity $[14,15]$. Indians account for highest in take of multiple types of tobacco products leading to high incidence of carcinoma oral cavity/ pharynx, esophagus and larynx[16]. Out of total 382 lymph node aspirated, there were $1.3 \%$ aspirate which was inconclusive and most common reason was hemorrhagic aspirate.

Histopathological correlation was available in 182 cases and the cytological diagnosis was discordant in mere $3.2 \%$ of cases. Two cases were cytologically diagnosed as granulomatous lymphadenitis and turned out to be malignant. One case was metastatic signet ring cell adenocarcinoma where the confusion was due to presence of granulomas along with signet ring cells resembling macrophages of sarcoidosis. And other case was Hodgkin's lymphoma and is a known tumor to be associated with granulomas. Careful search for presence of Reed Sternberg cells should be done. On reviewing the smears of FNAC, the smears were hemorrhagic with few granulomas. On careful screening the smears also showed few eosinophils and occasional mononuclear cells and was considered as interpretation and screening error. Three discordant cases were due to sampling error and the smears on review also don't show any representative cells. One case was diagnosed as reactive but in this case biopsy was advised to rule out low grade lymphoma because of the presence of monomorphic cell population. Thus, with proper technique and careful study, FNA of lymph nodes isa simple tool in the diagnosis of reactive, granulomatousas well as metastatic lesions and help detect occult primary malignancies inpatients. In our study, female preponderance was observed in thyroid lesions with similar to 1:4 by Rathod GB [17]. Benign thyroid lesions including inflammatory were more common (70.64\%) similar to Rathod GB [17] and Kishore HS [11].

Papillary Thyroid carcinoma (PTC) was most common thyroid malignancy in our study similar to other authors $[11,13,17]$. Valiya LG [13] also concluded thatsurgical intervention for a purely diagnostic purpose can be avoided in majority of thyroid lesions with cytological assessment. FNA serves dual role of diagnostic and the rapeutic in cystic thyroid lesions. In our study FNAC of salivary glands, Pleomorphic adenoma was most common lesionsimilar to Bhagat VM. [18]. However, studies by Kishor SH [11], Valiya LG [13] and Rathod GB [17] had different observation with inflammatory and reactive lesions comprising the majority. In our study oral lesion constitutes 13 cases diagnosed on FNAC. We got 11 (84.61\%) cases of Squamous cell carcinoma, followed by mucocele 1(7.69\%) and 1 case of round cell tumor (7.69\%). Similar results were found in a study done by Gupta N et al[19] which states salivary gland tumor and Squamous cell carcinoma are the most common lesion in the oral cavity.

In present study epidermal inclusion cyst was the most common lesion (55.88\%) on FNAC done on skin lesion. It is followed by inflammatory lesion (29.4\%). Same results were also generated by a study done by Bhagat VM et al [18] and Sreedevi P. [12]. In our study soft tissue swellings, showed lipoma as a predominant lesion.It is followed by 1 case of each Lymphangioma (4.16\%), spindle cell neoplasm (4.16\%), chordoma (4.16\%) and sarcoma (4.16\%) almost similar to miscellaneous lesions studied by Kishore SH [11] where epidermal cyst was $57.14 \%$ and lipoma was $23.8 \%$.

In our study we found 1 case of round cell tumor on FNAC from orbit. In present study, 3 cases of nasal cavity FNAC were done and two of them showed Squamous cell carcinoma and 1 case showed metastasis of Renal cell carcinoma.2 cases of Parathyroid FNAC was done, which showed primary hyperplasia and was associated with brown tumor of bone with lytic lesions. 


\section{Original Research Article}

Histopathological correlationwas evaluated in $47.2 \%$ of available cases for which a $94.7 \%$ concordance was observed. FNA of head and neck lesions has high histo pathological concordance rate of over $90 \%$ as observed by Nanik J [10] and Kishor SH [11]as well. Fifteen cases had discordant diagnosis, careful interpretation, radiological guided cytological assessment where in lesions were deep and ill defined, necessary and careful examination may have avoided the wrong diagnosis. Inconclusive findings were observed in $3.35 \%$ cases probably causes were non-cooperative patients especially pediatric population, small ill-defined small swellings, scanty aspirate, dry tap, haemorrhagic aspirates and nonrepresentative sampling mostly in deep neck swelling. Inflammatory /reactive and benign lesion comprised $58.29 \%$ cases in our study thus FNAC can help avoid unnecessary surgical biopsy and its attendant risks along with disadvantages such asscarring, greater duration of hospital stays and increased costs [20].

\section{Conclusions}

The present study conclude that Lymph node is the organ which is aspirated most and metastasis is the predominant lesion in our set-up. FNAC issimple, quick and cheap diagnostic tool to differentiate between neoplastic and non neoplastic lesions and helps avoid unnecessary surgical intervention. We recommend FNA as first line investigation in swellings of head and neck for best diagnostic and therapeutic approach.

What this study adds to existing knowledge? This is a tertiary care centre study based in capital city of central Indian state. it adds to the demographic knowledge of head and neck lesions as well as increased prevalence of metastatic lesion in lymph nodes compared to similar studies in other parts of India. Oral and upper respiratory tract can cerspresent as lymph node swellings in head and neck region and timely diagnosis of such lesions on FNA, a simple procedure which can be carried out in peripheral regions and villages in health camps can decrease the morbidity and mortality significantly.

\section{Contribution}

\begin{tabular}{|l|c|c|c|c|c|}
\hline & $\begin{array}{c}\text { Study conception } \\
\text { and design }\end{array}$ & $\begin{array}{c}\text { Acquisition of } \\
\text { data }\end{array}$ & $\begin{array}{c}\text { Analysis and } \\
\text { interpretation of data }\end{array}$ & $\begin{array}{c}\text { Drafting of } \\
\text { manuscript }\end{array}$ & $\begin{array}{c}\text { Critical } \\
\text { revision: }\end{array}$ \\
\hline Author 1 & Yes & yes & yes & yes & yes \\
\hline Author 2 & yes & yes & yes & yes & yes \\
\hline Author 3 & yes & yes & yes & yes & yes \\
\hline Author 4 & yes & & & yes & yes \\
\hline Author 5 & yes & & & & \\
\hline
\end{tabular}

Funding: Nil, Conflict of interest: None initiated

Permission from IRB: Yes

\section{References}

1. Abrari A, Ahmad SS, Bakshi V. Cytology in the otorhinolaryngologist's domain - a study of 150 cases, emphasizing diagnostic utility and pitfalls. Indian Journal of Otolaryngology and Head \& Neck Surgery. 2002;54(2):107-110. doi: 10.1007/ BF 02968727.

2. Ahmad T, Naeem M, Ahmad S, Samad A, Nasir A. Fine needle aspiration cytology (FNAC) and neck swellings in the surgical outpatient. J Ayub Med Coll Abbottabad. 2008 Jul-Sep; 20 (3):30-2.

3. Gamba PG, Messino A, Antoniello LM, Boccato P, Blandamura S, Cecchetto $G$, et al. A simple exam to screen superficial masses, FNAC. Med Pediatr Oncol, 1995:24:97-9.
4. Lee JC, Siow JK. Thyroid surgery--the Tan Tock Seng Hospital otolaryngology experience. Ann Acad Med Singapore. 2002 Mar;31(2):158-64.

5. Afridi S, Malik K, WaheedI.Role of fine needle aspiration biopsy and cytology in breast lumps J Coll Physicians Surg. Pak. 1995;5:75-7

6. Kevin G Burnand, Antony E Young, Jonathan Lucas et al. The New Aird's companion in surgical studies 3rd ed, Elsevier, Churchill Livings tone. 2005 P$179-81$.

7. Layfield LJ. Fine-needle aspiration of the head and neck. Pathology (Phila). 1996; 4 (2):409-38. 
Original Research Article

8. Bagga PK, Mahajan NC. Fine needle aspiration cytology of thyroid swellings: how useful and accurate is it? Indian J Cancer. 2010 Oct-Dec;47(4):437-42. doi: 10. 4103/0019-509X.73564.

9. Martin HE, Ellis EB. Biopsy by needle puncture and aspiration. Ann Surg. 1930 Aug;92(2):169-81.

10. Nanik J, Rathore H, Pachori G, Bansod P, Ratnawat K. Cytomorphology of head and neck lesions: A study in tertiary care hospital. Panacea J Med Science. 2015; 5:145-9.

11. Kishore SH, Rajshri DP, Nandkumar DV,Yogesh T.Spectrum of FNAC in palpable head and neck lesions in a tertiary care hospital in india- a 3 years study; Indian Journal of Pathology and Oncology, January March 2015; 2(1); 7-13.

12. Sreedevi P, Kishore Ch, Pararkusa NC. Diagnostic Role of FNAC in evaluation of Head and Neck Lesions IOSR Journal of Dental and Medical Sciences. Volume 15, Issue 9 September 2016,11-13

13. Valiya LG, Padhariya BB, Baxi SN. Spectrum of FNAC in Palpable Head and Neck Lesions In a tertiary care hospital in Western India - A 2 years study. Journal of Dental and Medical Sciences. 2016 June; 15(6): 14-19.

14. Alam K, Khan A, Siddiqui F, Jain A, Haider N, Maheshwari V. Fine needle aspiration cytology (FNAC): A handy tool for metastatic lymphadenopathy. Int J Pathol. 2010;10:2.
15. Hirachand S, Lakhey M, Akhter J, Thapa B. Hirachand S1, Lakhey M, Akhter J, Thapa B. Evaluation of fine needle aspiration cytology of lymph nodes in Kathmandu Medical College, Teaching hospital. Kathmandu Univ Med J (KUMJ). 2009 AprJun; 7 (26):139-42.

16. Rastogi T, Devesa S, Mangtani P, Mathew A, Cooper N, Kao R, Sinha R. Cancer incidence rates among South Asians in four geographic regions: India, Singapore, UK and US. Int J Epidemiol. 2008 Feb;37 (1): 147-60. Epub 2007 Dec 19.

17. Rathod GB, Parmar P. Fine needle aspiration cytology of swellings of head and neck region. Indian J Med Sci. 2012 Mar-Apr;66(3-4):49-54. doi: 10.4103/ 0019-5359.110896.

18. Bhagat VM, Tailor HJ, Saini PK et al. Fine needle aspiration cytology in non-thyroid head and neck masses-a descriptive study in teritary care hospital. National Journal of Medical Science Research 2013;3 (3): 273-76.

19. Gupta N, Banik T, Rajwanshi A, Radotra BD, Panda N, Dey P, Srinivasan R, Nijhawan R. Fine needle aspiration cytology of oral and oropharyngeal lesions with an emphasis on the diagnostic utility and pitfalls. J Cancer Res Ther. 2012 Oct-Dec;8(4):626-9. doi: 10. 4103 /0973-1482.106581.

20. Karayianis SL, Francisco GJ, Schumann GB. Clinical utility of head and neck aspiration cytology. Diagn Cytopathol. 1988;4(3):187-92.

\section{How to cite this article?}

Meenai F.J, Jain R, Ojha S, Sawke G.K, Gupta S. Study of spectrum of head and neck lesions diagnosed on fine needle aspiration cytology (FNAC). Trop J Path Micro 2018;4(1):93-100. doi: 10.17511/jopm.2018.i1.17. 